\title{
Are All Learners Created Equal? A Quantitative Analysis of Academic Performance in a Distance Tertiary Institution
}

\author{
Zlatko J Kovačić and John Steven Green \\ The Open Polytechnic of New Zealand, Wellington, New Zealand
}

\author{
Zlatko.Kovacic@openpolytechnic.ac.nz \\ John.Green@openpolytechnic.ac.nz
}

\begin{abstract}
This paper reports initial research results on the relationship between student learning styles and academic achievement in a distance education computing course with Internet-based student support. The learning styles of students in a computer concepts class were evaluated and classified according to the Felder-Soloman Learning Style Index. We have identified statistically significant differences in performance between different learner types, i.e. groups of students with different learning preferences. The best course performance in both course components: in-course assessment and final examination was identified in students with reflective, sensing, verbal and global learning preferences. One possible explanation of this result might be that the current teaching styles and distance learning environment (course material and online student support) gives an advantage to this type of learner. To test this hypothesis we are planning changes in the learning environment and methodology to cater for a variety of student learning styles. We can then test if academic achievement has been improved by comparing it with the results presented in this paper.
\end{abstract}

Keywords: Academic performance, Learning styles, Felder-Solomon Index of Learning Styles, Computer concepts, Distance education

\section{Introduction}

This paper presents the results of an empirical study of the learning styles of a group of students on a computer concepts course at The Open Polytechnic of New Zealand in 2003. The Open Polytechnic is the only specialist provider of open and distance education in New Zealand. Computer Concepts is a compulsory course that forms part of the New Zealand Diploma in Business. The Diploma is a level 4 course on the New Zealand Qualifications Authority 8 level framework. The course emphasises the use of computers and information systems in a business scenario. The course has a large practical component of $60 \%$ covering applications, the Internet and the operating system. The course uses electronic forums and bulk email as the main means of learning support in addition to telephone and mail. Support is provided both by the lecturer and students via

Material published as part of this journal, either on-line or in print, is copyrighted by Informing Science. Permission to make digital or paper copy of part or all of these works for personal or classroom use is granted without fee provided that the copies are not made or distributed for profit or commercial advantage AND that copies 1) bear this notice in full and 2) give the full citation on the first page. It is permissible to abstract these works so long as credit is given. To copy in all other cases or to republish or to post on a server or to redistribute to lists requires specific permission from the publisher at Publisher@InformingScience.org forum based peer support. Participation in the forums is an integral part of the assessment. With a semester length of 17 weeks the course attracts upwards of 180 students per semester. These are some demographics for the students enrolled in the course: 
- $66 \%$ of students are female

- Most students are over 30

- $66 \%$ have no tertiary qualification

- $60 \%$ are wage or salary workers

There are many factors which influence academic performance in addition to learning styles such as gender, age, work experience (Dille \& Mezack, 1991). The intention of the several strands of our research is to identify those students who are likely to require additional learning support. In this paper we concentrate on learning styles, other aspects will be covered in further papers by the authors. The main objective of this paper was to identify the relationship between the learning styles of the students and their academic achievement on the course. More specifically the data gathered for this paper was used to address the following questions:

- does the preferred learning style of the student affect their academic performance on the course?

- is someone with a particular learning style more likely to succeed on the course than any other?

- is someone with a particular learning style more likely to fail on the course than any other?

- can we identify students who require additional learning support from their learning style profile?

While it is preferable that a student uses and develops an array of learning styles to deal with course content and the real world, this research deals only with each student's currently preferred learning style. This is in line with the previously stated purpose of the research i.e. the identification of those students that may require additional learning support. We use the terms 'learning preferences' and 'learning styles' interchangeably throughout the paper though we are aware of the differences between the two concepts as discussed by Sadler-Smith (1997).

Academic performance will be measured in terms of the final grade achieved rather than perceived learning as the authors prefer to measure actual learning rather than perceived learning. Perceived learning is likely to be subjective and does not allow a comparison of one student with another since self perception will differ from one individual to another and may be more likely to indicate overall confidence levels than actual learning.

Though there have been numerous studies on the relationship between preferred learning styles and academic performance in both IT and non-IT subject areas and in distance and contact courses (Aragon, Johnson \& Shaik, 2002; Fowler, Allen, Armarego \& Mackenzie, 2000; McKenzie, Rose \& Head, 1999; Neuhauser, 2002; Papp, 2001; van Zwanenberg \& Wilkinson, 1999; Zywno \& Waalen, 2002), evidence remains contradictory. For example for first year programming courses, Thomas, Ratcliffe, Woodbury and Jarman (2002) suggest that there is a relationship between student learning style and academic performance, whilst Byrne and Lyons (2001) suggest that no such relationship exists.

The first section provides a brief overview of learning styles models, summarising the Kolb and Felder-Silverman learning styles models. In the second section the learning styles instrument is described. In the third section data and methodology are discussed. The fourth section presents the learning styles results and academic performance along with critical comments. Finally there are some recommendations on how, in a similar class, it might be possible to identify and improve the performance of those students whose academic achievement could be below the class average by means of their learning styles profile. 


\section{Learning Styles Models}

The taxonomy of learning styles models uses Curry's 'Onion' Model (Curry, 1983) to describe and explain the relationship between the different learning styles models and the way learners learn. The core layer of Curry's 'Onion' Model deals with the most stable component of style, i.e. cognitive personality style. Models from the middle layer are labeled as 'information processing models' which concentrate on the way learners obtain, sort, store and utilise information. The models from this layer are more stable than the models from the outer layer ('instructional preference models') but are still modifiable by learning strategies. Finally, environmental, emotional, sociological, physiological and psychological features of both learners and teachers are the concern of the models from the outer layer - 'instructional preference models'. An alternative generalisation of learning styles models, i.e. a metamodel, has been developed by Gordon and Bull (2004) but is however appropriate only for the 4-cycles type of learning styles models.

One of the main reasons for our particular interest in the information processing layer comes from the fact that teachers can influence it by using different learning strategies (Atkins, Moore, Sharpe, \& Hobbs, 2001). The information processing layer comprises, among other models, Kolb's experiential learning cycles model (Kolb, 1984), one of the most cited and the most often used to identify learner's preferences. The model we use in this paper is the Felder-Silverman model (1988) which partly belongs to the same category as Kolb's model. There appears to be a close relationship between the Felder-Silverman model and the Kolb learning style model. They share the same two dimensions: Processing (the preferred way learners are processing information, with two poles: Actively/Reflectively) and Perception (the preferred way learners are perceiving information, with two poles: Sensing/Intuitive) as we illustrate in Figure 1. However, the Felder-Silverman model also partly belongs to the inner layer, i.e. cognitive personality style, because it adds two new dimensions, which address the learners' approaches to adapting and assimilating information. These two dimensions are: Input (the preferred way learners are inputting information, with two poles: Visually/Verbally) and Understanding (the preferred way learners are adapting information, with two poles: Sequentially/Globally).

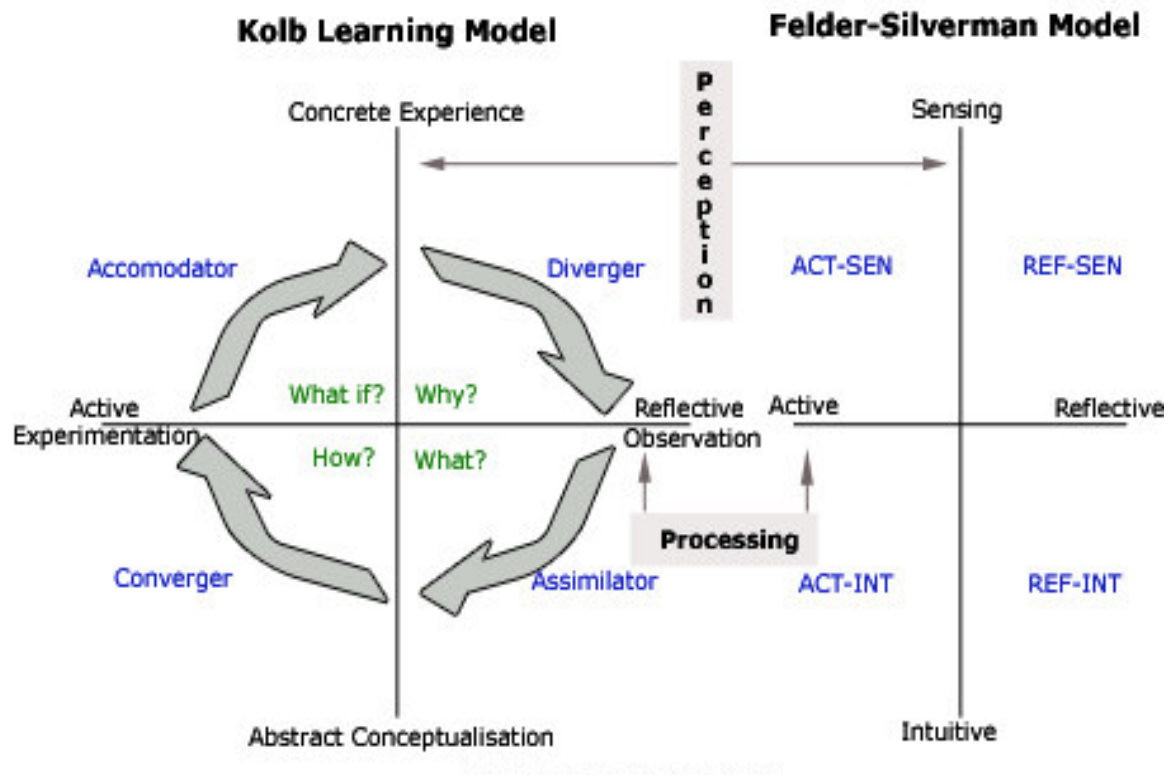

Adapted from Kolb (1984)

Figure 1: Kolb and Felder-Silverman learning models 
The Kolb model uses the learner's experience as a starting point in the learning process. Learners are perceived as passing through four stages of learning. Initially they are experimenting with the topic, accumulating enough concrete experience to be able to reflect, in the second stage, on the observations gathered in the concrete experimenting stage. As a result of reflective activities learners derive abstract concepts and make generalisations in the third abstract conceptualisation stage. Finally, new concepts are subject to testing to see if they provide a reliable explanation in new situations. In other words, learners begin a new learning cycle, gathering new evidence (concrete experience). Though learners are moving through each stage they are likely to have a preferred learning mode. By looking at the quadrants, Kolb identified four types of learners in this model: Diverger (creative, generates alternatives), Assimilator (defines problems, creates theoretical models), Converger (practical applications, makes decision) and Accomodator (takes risks, gets things done), as we have labeled them in Figure 1. We can also identify these learners by the type of question they would ask while they are learning: "Why?", "What?", "How?" and "What if?"

In Table 1 of the Felder-Silverman model we are summarising what typical learners from each of the four dimensions of the model will like and dislike in the learning environments or teaching styles. Later, we use these characteristics to recommend changes in the learning environment and strategies.

Table 1: Characteristics of typical learners in the Felder-Solomon model

\begin{tabular}{|c|c|c|c|}
\hline \multicolumn{2}{|c|}{ Dimension } & \multirow{2}{*}{\begin{tabular}{l}
\multicolumn{1}{c}{ Likes } \\
To try things out, to work within \\
a group, to discuss and explain to \\
others
\end{tabular}} & \multirow{2}{*}{$\begin{array}{c}\text { Dislikes } \\
\text { Attending lectures, taking notes } \\
\text { and not doing anything physical }\end{array}$} \\
\hline Processing & Active & & \\
\hline & Reflective & $\begin{array}{l}\text { To think before doing something, } \\
\text { to work alone, or as a pair }\end{array}$ & $\begin{array}{l}\text { Sitting, listening to lectures and } \\
\text { taking notes }\end{array}$ \\
\hline \multirow[t]{2}{*}{ Perception } & Sensing & $\begin{array}{l}\text { To learn facts, to solve problems } \\
\text { by well-established methods, to } \\
\text { be patient with details, to memo- } \\
\text { rise facts, to work slower, to do } \\
\text { hands-on work }\end{array}$ & $\begin{array}{l}\text { Complications and surprises, } \\
\text { courses not related to the real } \\
\text { world, a timed examination that } \\
\text { focuses on the ability to quickly } \\
\text { manipulate symbols and see } \\
\text { patterns }\end{array}$ \\
\hline & Intuitive & $\begin{array}{l}\text { To discover possibilities and } \\
\text { relationships, to be innovative, to } \\
\text { grasp new concepts, abstractions } \\
\text { and mathematical formulation, to } \\
\text { work faster }\end{array}$ & $\begin{array}{l}\text { Repetition, courses that in- } \\
\text { volves lot of memorisation and } \\
\text { routine calculation }\end{array}$ \\
\hline \multirow[t]{2}{*}{ Input } & Visual & $\begin{array}{l}\text { Pictures, diagrams, flow charts, } \\
\text { time lines, films, multimedia } \\
\text { content and demonstrations }\end{array}$ & $\begin{array}{l}\text { Text without some visual com- } \\
\text { ponents }\end{array}$ \\
\hline & Verbal & Written and spoken explanations & $\begin{array}{l}\text { Visual presentation without } \\
\text { written and spoken explanation. }\end{array}$ \\
\hline \multirow[t]{2}{*}{ Understanding } & Sequential & $\begin{array}{l}\text { To learn and think in lin- } \\
\text { ear/sequential steps }\end{array}$ & \\
\hline & Global & $\begin{array}{l}\text { To learn in large leaps, absorbing } \\
\text { material almost randomly, i.e. } \\
\text { holistic learner }\end{array}$ & \\
\hline
\end{tabular}




\section{Learning Styles Instrument}

In this paper we used the learning styles instrument known as the Felder-Soloman's Index of Learning Styles (ILS) (Felder \& Silverman, 2003), which is based on the Felder-Silverman learning style model. An overview of adult learning style inventory models is given in Hickcox (1995).

The reasons we opted for this particular learning styles instrument are as follows:

1. It covers all four learning styles dimensions and is based on a sound theoretical model.

2. This instrument is simple to use and the results obtained from this study are easy to interpret and can be applied easily.

3. The instrument has been widely tested and used successfully in helping to guide the design, development and use of effective learning environments.

4. This instrument has good validation results (Zywno, 2003), which makes this instrument reliable in detecting preferred learning styles among students.

The Felder-Solomon ILS questionnaire is constructed as a bi-polar instrument across four dimensions: Processing (with poles: Active/Reflective), Perception (Sensing/Intuitive), Input (Visual/Verbal) and Understanding (Sequential/Global). The dichotomous learning style dimensions of this model are continuous and not discrete categories. This means that the learner's preference on a given scale does not necessarily belong to either one of the poles. It may be strong, mild, or almost non-existent.

The instrument consists of 11 questions for measuring each of the four dimensions, and thus a total of 44 questions. Each question along a dimension is designed to determine if a respondent tends to belong to one category or another on that dimension. It does so by asking the respondent to choose only one of two options where each option represents each category. For example the Perception dimension has two categories: Sensing and Intuitive. One of the Perception dimension questions in the instrument is "I find it easier (a) to learn facts or (b) to learn concepts". A respondent who chooses (a) is one who tends to be a sensing learner, while one who chooses (b) tends to be an intuitive learner. A respondent is classified as belonging to a particular category, for example, sensing instead of intuitive on the Perception dimension, if he or she chooses more of the options that correspond to those of sensing learners. Since there are 11 questions for each dimension, a respondent is always classifiable along each dimension. The range of data for each dimension is from 0 to 11. Since there are four dimensions and each dimension has two poles there are 16 possible combinations, i.e. types of learner, in this model.

\section{Data}

We administered the Felder-Solomon (2003) Index of Learning Styles instrument as an integral part of a compulsory in-course assessment, the Assessed Project. Students identified their learning style by replying to the online questionnaire at the North Carolina State University web site, host of the ILS. Of 117 students who submitted the Assessed Project, 92 of them (79\%), completed the online questionnaire and sent in their learning style results. Unfortunately not all of the students who submitted their learning styles results sat the final exam. In the later analysis we present the learning styles results for two sample sizes of 92 and 67. The larger data set includes all students who submitted their learning styles results. The smaller data set includes only those who submitted the Assessed Project with their learning styles results and sat the final exam. The 12 students who completed the course but didn't submit their learning styles analysis were excluded from further analysis. 


\section{Results}

The Felder-Solomon learning styles frequencies of the Open Polytechnic of New Zealand computer concepts students are listed in Table 2 for two sample sizes: a larger data set $(\mathrm{N}=92)$ for all those who submitted their learning styles results and a smaller data set $(\mathrm{N}=67)$, for those who

Table 2: Students' learning styles frequencies

\begin{tabular}{|c|c|c|c|c|}
\hline Sample size & Active & Sensing & Visual & Sequential \\
\hline $\mathrm{N}=92$ & $50 \%$ & $86 \%$ & $82 \%$ & $58 \%$ \\
$\mathrm{~N}=67$ & $51 \%$ & $93 \%$ & $79 \%$ & $57 \%$ \\
\hline
\end{tabular}
submitted their learning styles results and sat the final exam.

From Table 2 we see that the students' learning styles profile for the smaller data set closely matches the students' learning styles profile in the larger data set (there is a 7\% discrepancy in sens-

ing frequencies only). This would suggest that the students' learning styles profile is stable across the different sample sizes. It appears that the class is quite balanced on the Processing dimension (50:50 split between active and reflective learners). The result indicates that the computer concepts students are extremely sensing ( $93 \%$ in the smaller data set) with only a few Intuitive learners. They prefer visual input of information rather than verbal. Slightly more than half of the class understand information sequentially rather than globally. Based on these learning styles frequencies we have defined the 'dominant' student (the most frequent) learning profile as active, sensing, visual and sequential.

Table 3: Mean course assessments marks for different dimensions of learning styles

\begin{tabular}{|l|c|c|c|c|}
\hline Learning style & $\begin{array}{c}\text { Assessed } \\
\text { Project }\end{array}$ & $\begin{array}{c}\text { Final } \\
\text { Exam }\end{array}$ & $\begin{array}{c}\text { Course } \\
\text { Mark }\end{array}$ & $\begin{array}{c}\text { Sample } \\
\text { size }\end{array}$ \\
\hline Active & 81.2 & 61.2 & 73.2 & 34 \\
Reflective & 78.2 & 63.3 & 72.2 & 33 \\
F-ratio & 0.70 & 0.35 & 0.10 & - \\
P-value & 0.41 & 0.56 & 0.76 & - \\
\hline Sensing & 79.7 & 62.3 & 72.8 & 62 \\
Intuitive & 80.1 & 60.7 & 72.3 & 5 \\
F-ratio & 0.00 & 0.06 & 0.01 & - \\
P-value & 0.96 & 0.81 & 0.94 & - \\
\hline Visual & 78.7 & 60.8 & 71.5 & 53 \\
Verbal & 83.8 & 67.4 & 77.5 & 14 \\
F-ratio & 1.34 & 2.42 & 2.20 & - \\
P-value & 0.25 & 0.13 & 0.14 & - \\
\hline Sequential & 82.2 & 62.8 & 74.4 & 38 \\
Global & 76.6 & 61.5 & 70.5 & 29 \\
F-ratio & 2.46 & 0.13 & 1.50 & - \\
P-value & 0.12 & 0.72 & 0.23 & - \\
\hline Total & 79.7 & 62.2 & 72.7 & 67 \\
\hline
\end{tabular}

The mean marks for each component of the course assessments (an in-course assessment called the assessed project and the final exam) were computed and a comparison of the different dimensions of learning styles is shown in Table 3. The table also contains a value of the F-ratio and P-value for each pair of mean values and for each course assessment. The Pvalue indicates the likelihood of obtaining a difference between mean values as large as that observed if it occurred simply from randomness in the data. A low Pvalue implies that we 
would probably not observe such a large difference from purely random data and the difference must be the result of some systematic effect. By convention, we usually label any difference with a P-value of 0.05 or less as meaningful, that is, statistically significant.

In the case of the Assessed Project the largest average marks were found for verbal (average mark 83.8) and sequential (82.2) learners. In the case of the final exam the highest average marks were found for verbal (67.4) and reflective (63.3) learners.

Active, sensing, verbal and sequential learners scored a higher course mark than their opposites (reflective, intuitive, visual and global). However, the large P-values in Table 3 suggest that practically none of the differences between their marks are statistically significant. They are only marginally significant in the case of the Visual/Verbal dimensions for the final exam and the overall course mark (at the 13 and 14\% level respectively), and for the Sequential/Global dimensions for the Assessed Project (at the 12\% level). The Assessed Project may give advantage to sequential learners as they scored 5.6\% higher marks on average than global learners. The reason for this could be explained by the structure of the Assessed Project. We have constructed the Assessed Project with quite specific requirements asking them to build a typical business application (using wordprocessing, spreadsheeting, database and electronic communication) and by following quite strict, step-by-step instructions which obviously give advantage to sequential learners. On the other hand, the final examination may give advantage to verbal learners as they scored $6.6 \%$ higher marks on average than their counterpart, visual learners. Again, this result could be expected for quite obvious reasons. The final exam questions are given in a purely written format without any graphical element and we are expecting students to answer these questions the same way, i.e. in a written format. Therefore those students who learn visually may be disadvantaged in the final exam. However, we must emphasise again that the evidence is not particularly strong taking into account high P-values between 12-14\% for these three differences (between Assessed Project marks for sequential and global learners and between final exam and overall course mark for visual and verbal learners).

\section{Table 4: Correlations between course assessments marks and different dimensions of learning styles}

\begin{tabular}{|l|c|c|c|}
\hline Dimension & $\begin{array}{c}\text { Assessed } \\
\text { Project }\end{array}$ & $\begin{array}{c}\text { Final } \\
\text { Exam }\end{array}$ & $\begin{array}{c}\text { Course } \\
\text { Mark }\end{array}$ \\
\hline Active & $0.14(0.27)$ & $-0.05(0.67)$ & $0.07(0.58)$ \\
Sensing & $0.14(0.27)$ & $0.13(0.28)$ & $0.15(0.22)$ \\
Visual & $0.03(0.79)$ & $-0.03(0.78)$ & $0.01(0.95)$ \\
Sequential & $0.27(0.03)$ & $0.13(0.30)$ & $0.24(0.05)$ \\
\hline
\end{tabular}

We have calculated the Pearson's correlation coefficients between course assessments marks and learning styles scores for each dimension of the FelderSilverman model and presented them in Table 4. The figure between the brackets shows $\mathrm{P}$-value, i.e. the level of significance. The P-value indicates the likelihood of

obtaining a correlation coefficient as large as that observed if it occurred simply from randomness in the data. A low P-value implies that we would probably not observe such a large correlation coefficient from purely random data and the coefficient must be the result of a linear relationship between observed series.

There is a positive and statistically significant relationship between the Sequential dimension and the Assessed Project mark (the correlation coefficient is 0.27, which is significant at the 3\% level), as well as for the overall course mark (0.24, at the 5\% level). Students who gain higher marks on the Assessed Project and consequently a higher overall course mark often have a score on the Understanding dimension closer to the sequential pole. This result carries a similar message to the comparison between average marks for sequential and global learners given above in Table 3 (for the Assessed Project the P-value is 12\%), though this time with higher statistical sig- 
nificance (the P-value is 3\%). This result may suggest that the Assessed Project could give an advantage to sequential learners.

Almost all correlation coefficients have a positive sign, with two exceptions: for Active/Reflective and Visual/Verbal dimensions, both are negatively related to the final exam marks. However, 10 out 12 of the correlation coefficients in Table 4 are not statistically significant. This result means we can accept the hypothesis that the other learning styles dimensions other than Sequential/Global have no significant impact on the course performance.

In the next stage of analysis we take a more holistic approach to learners. As we know, with 4 dimensions and two poles on each dimension in the Felder-Silverman model we have 16 distinctive types of learners. However in this course more than $80 \%$ of the class belonged only to one of the five types of learners listed in Table 5. Our hypothesis that these five types of learners perform equally well was rejected for the Assessed Project and for the overall course mark at the $4 \%$ level. Our hypothesis of equal average final exam marks between these groups was accepted.

Table 5: Mean course assessments marks for different types of learners

\begin{tabular}{|c|c|c|c|c|}
\hline Learner's type & $\begin{array}{c}\text { Assessed } \\
\text { Project }\end{array}$ & $\begin{array}{c}\text { Final } \\
\text { Exam }\end{array}$ & $\begin{array}{c}\text { Course } \\
\text { Mark }\end{array}$ & $\begin{array}{c}\text { Sample } \\
\text { size }\end{array}$ \\
\hline ACT-SEN-VIS-SEQ & 81.5 & 60.3 & 73.1 & 19 \\
REF-SEN-VIS-SEQ & 82.3 & 65.2 & 75.5 & 11 \\
REF-SEN-VIS-GLO & 65.8 & 54.1 & 61.1 & 10 \\
ACT-SEN-VIS-GLO & 79.4 & 61.0 & 72.0 & 9 \\
REF-SEN-VRB-GLO & 84.8 & 69.4 & 78.6 & 7 \\
\hline F-ratio & 2.71 & 1.46 & 2.71 & - \\
P-value & 0.04 & 0.23 & 0.04 & - \\
\hline Total & 78.9 & 61.4 & 71.9 & 56 \\
\hline
\end{tabular}

The learners from the fifth group (REF-SEN-VRB$\mathrm{GLO}$ - reflectivesensing-verbalglobal) make only $10 \%$ of the class, but they have the best performance in both assessment components (Assessed Project and the final exam) and have the highest overall course per-

formance, scoring the highest marks amongst all other types of learners. This may suggest that the Computer Concepts course is designed and taught in a way that caters for this particular type of learner or that this type of learner is generally more perceptive or a better learner. Further research which would explicitly test these propositions is required. On the other side, the reflectivesensing-visual-global type of learner (15\% of the class) has the poorest course performance in terms of having the lowest average mark for the Assessed Project and the final exam, and consequently scoring the lowest overall course mark. Comparing these two opposite types of learners we can say that the way they are inputting information (visually or verbally) is the most significant factor which influences their course performance. Distance education courses in general by the very nature of the learning mode may give advantage to verbal learners. The course material, weekly bulk emails, and newsletters used on this course are all written material, with few graphical elements. Even the discussion forums used for peer-to-peer and tutors support are dominantly written discourse, if we ignore the fact that we can insert emoticons and attached graphic/multimedia file to the message. With the lack of graphical elements (charts, diagrams, multimedia elements, etc.) in the course material, visual learners could be disadvantaged, though they make up $80 \%$ of the class. With the opportunity for including multimedia components in the course material brought by the Internet technologies, an effort should be made to adjust the learning environment in a way that suits the majority of the learners. Consequently the course performance would be expected to improve as a result of these changes. This was confirmed by But- 
ler and Mautz in their 1996 article where they found, among accounting students, that the visual learners benefited most from multimedia presentations.

\section{Implications for Instructional Design and Teaching}

The identified differences in course performance between the different types of learners should be addressed and an effort made to introduce changes in the course material from an instructional design perspective (McLoughlin, 1999). Modifications in the current learning strategies should be made to help each learner who scored below the average mark to increase his/her educational performance. Of course to some extent students should also be exposed to teaching styles and instructional material which is different from their preferences to prepare them for the real world (Felder, 1993, 1996; Montgomery \& Groat, 1998).

From the results presented in this paper we can make some recommendations for instructional design. Multimedia elements should be included in course materials (Montgomery, 1995). This is what the $80 \%$ visual learners in the class would probably need. This would also probably be appreciated by global and active learners. According to the results presented by Zywno and Wallen in their 2002 article "hypermedia instruction was particularly effective for Active and Global students". And further "hypermedia is more effective in reaching all types of students and reducing differences in the academic performance among different learning styles". The learning environment should be designed so that students have control of their learning experiences. They should have an option to choose between different paths throughout the course material, for example between one with more visual or more verbal input. For the global learners a course map and learning material which gives a wide perspective, i.e. a global overview of the course, would be likely to improve their course performance.

Our course performance analysis results did not completely support the hypothesis that there is a statistically significant impact on students' academic performance caused by their learning style preferences. Weak evidence of a relationship and impact on academic performance has been found for the way students on this course are inputting and understanding the information. What were statistically significant were the differences between learner types listed in Table 5. By changing the current learning strategies and learning environment in the future we are going to test the hypothesis that they have a significant impact on the students' performance favoring students with certain kinds of learning style preferences.

In his 1993 seminal article Felder gave advice to academics to take account of the needs of the polar extremes in each learning dimension and to provide opportunities for all types of learners. However, as we have said, to some extent students should be exposed to teaching styles that are different from their preferences, to increase their readiness for the real world. Of course when academics try to address the range of learning styles, other factors should be considered as well, such as resources, academic staff skills and the time involved.

We have used a list of Felder's recommendations to suggest a few changes in the learning strategies that would increase students' academic performance of Computer Concepts students:

1. Since discussion forums are written discourse per se, tutors should use attachments with screen shots (visual) of each important step (sequential) in designing a business application (wordprocessing, spreadsheeting and database). Alternatively a PowerPoint presentation with animated slides or multimedia elements (video, Macromedia Flash animation, etc.) and speaker's notes would probably enrich the learning experience because of students' preference for visual input of information.

2. So far the Assessed Project is strictly sequentially designed with five independent sections. We think that it should provide clear connections between tasks to enable global 
learners to relate current materials/tasks to the relevant materials in the same or other courses and to everyday experience.

3. The final exam questions should include, if possible, flow charts and diagrams (visual) to help students to understand what the question is about. Students could be also encouraged to provide answers in a diagrammatic format where possible.

4. To bridge the gap in the Perceiving and Understanding dimension between themselves and students, tutors should provide more examples (sensing) to illustrate how to design a business application in a step-by-step (sequential) manner. This is quite important because there is a large $(60 \%)$ practical component covering word processing, the use of spreadsheets, database management and the Internet.

5. Tutors can help students to develop a broader range of learning styles by creating assignments that access the full spectrum of learning styles. These would be multidimensional packages containing activities suited to each of the learning styles.

6. Felder advises tutors to make more use of handouts for information exchange to allow more time for student interaction around that information, and to allow time for reflection (reflective). Interestingly this is the teaching method used at The Open Polytechnic and many other distance institutions. Increased opportunities for interaction and reflection would be likely to increase academic performance.

7. Our research suggests that the adoption of a strategy to identify learning profiles would be likely to increase academic performance by enabling more targeted learner support. For example, students identified as reflective-sensing-visual-global were less successful (scoring below the class average) should be carefully monitored and given learning support tailored to their learning profile.

\section{Conclusion}

This paper has reported the results of an empirical study of the relationship between learning styles of students and their academic performance. We have identified the differences in learning styles using the Felder-Soloman Index of Learning Styles. We have found weak evidence of a positive relationship between students' academic performance and the way they are inputting (visually/verbally) and understanding (sequentially/globally) the information. We would say our results are more consistent with the results of Byrne \& Lyons (2001), who suggested that there is no relationship between preferred learning styles and the academic performance of IT students, than those presented for the first year programming course by Thomas, Ratcliffe, Woodbury and Jarman (2002). This conclusion was confirmed by the initial results we have obtained on the same Computer Concepts course in the next semester.

When we adopt a more holistic view of students however, and view them as multidimensional beings, we see evidence a much stronger relationship between certain learner types and academic performance (Table 5). For example, reflective-sensing-verbal-global students have the best overall course performance. Conversely reflective-sensing-visual-global students have the poorest course performance. We can say that the way students input information is the most significant factor which influences their course performance. These learner types will be the subject of our future research. To improve course performance among types of learners listed in Table 5 who scored below the average mark, we have recommended some changes in the learning environment design and in the learning strategies which hopefully would bring those students closer to the rest of the class.

This research sets the foundation for future work on learning styles in the Open Polytechnic of New Zealand. We are planning to test a hypothesis that the differences in course performance 
between different types of learners could be attributed to the current teaching styles and distance learning environment (course material and online student support), i.e. that the learning environment and strategies give an advantage to particular types of learners. To test this hypothesis we are planning to make changes in the learning environment and methodology to cater for a variety of student learning styles. Then we can test if the academic achievement has been improved by comparing it with the results presented in this paper. We will also test the effectiveness of additional learning support on reflective-sensing-visual-global students.

\section{References}

Aragon, S. R., Johnson, S. D., \& Shaik, N. (2002). The influence of learning style preferences on student success in online versus face-to-face environments. The American Journal of Distance Education, 16 (4), 227-244.

Atkins, H., Moore, D., Sharpe, S., \& Hobbs, D. (2001, June). Learning style theory and computer mediated communication. ED-MEDIA 2001, Tampere, Finland. Retrieved June 10, 2003 from http://oufcnt5.open.ac.uk/ Hilary_Atkins/edmedia.htm

Butler, \& Mautz (1996). Multimedia presentations and learning: A laboratory experiment. Issues in Accounting Education, 11 (2), 259-280.

Byrne, P., \& Lyons, G. (2001). The effect of student attributes on success in programming. Proceedings of the 6th annual conference on Innovation and technology in computer science education, Canterbury, United Kingdom, 49-52.

Curry, L. (1983). An organization of learning styles theory and constructs. In L. Curry (Ed.), Learning style in continuing education (pp. 115-131). Dalhousie University.

Dille, B. \& Mezack, M. (1991). Identifying predictors of high risk among community college telecourse students. The American Journal of Distance Education, 5 (1), 24-35.

Felder, R. M. (1993). Reaching the second tier - Learning and teaching styles in college science education. Journal of College Science Teaching, 78 (7), 674-681. Retrieved June 10, 2003 from http://www.ncsu.edu/felder-public/Papers/Secondtier.html

Felder, R. M. (1996). Matters of style. ASEE Prism, 6 (4), 18-23. Retrieved June 10, 2003 from http://www.ncsu.edu/felder-public/Papers/LS-Prism.htm

Felder, R. M., \& Silverman, L. K. (1988). Learning and teaching styles in engineering education. Engineering Education, 78 (7), 674-681.

Felder, R. M. \& Soloman, B. A. (2003). Index of learning styles questionnaire. Retrieved October 10, 2003 from http://www.engr.ncsu.edu/learningstyles/ilsweb.html.

Fowler, L., Allen, M., Armarego, J. \& Mackenzie, J. (2000, February). Learning styles and CASE tools in software engineering. Proceedings of the 9th Annual Teaching Learning Forum, Perth, Australia. Retrieved September 1, 2003 from http://cea.curtin.edu.au/tlf/tlf2000/fowler.html

Gordon, D. \& Bull, G. (2004, March). The nexus explored: A generalised model of learning styles. $15^{\text {th }}$ International Conference of Society of Information Technology \& Teacher Education, Atlanta, Georgia, USA.

Hickcox, L. K. (1995). Learning styles: A survey of adult learning style inventory models. In R. R. Sims, \& S. J. Sims (Eds.), The importance of learning styles (pp. 25-46). USA: Greenwood Press.

Kolb, D. (1984). Experiential learning: Experience as the source of learning and development. Englewood Cliffs, NJ: Prentice-Hall.

McKenzie, J., Rose, S. \& Head, C. (1999, June). A study of the relationship between learning styles profiles and performance on an on-line team-based collaborative learning project. In J. Hill, S. Armstrong, M. Graff, S. Rayner \& E. Sadler-Smith (Eds.), Proceedings of the 4th Annual Conference of the European Learning Styles Information Network. Preston: University of Central Lancashire. 313-332. 
McLoughlin, C. (1999). The implications of the research literature on learning styles for the design of in structional material. Australian Journal of Educational Technology, 15 (3), 222-241.

Montgomery, S. M. (1995). Addressing diverse learning styles through the use of multimedia. Proceedings of the ASEE/IEEE Frontiers in Education '95 Conference, Session 3a2 - Multimedia 1. Retrieved June 10, 2003 from http://fie.engrng.pitt.edu/fie95/3a2/3a22/3a22.htm

Montgomery, S. M. \& Groat, L. N. (1998). Student learning styles and their implications for teaching, CRLT Occasional Papers, No. 10, The Center for Research on Learning and Teaching, The University of Michigan.

Neuhauser, C. (2002). Learning style and effectiveness of online and face-to-face instruction. The American Journal of Distance Education, 16 (2), 99-113.

Papp, R. (2001, December). Student learning styles and distance learning. Proceedings of the $16^{\text {th }}$ Annual Conference of the International Academy for Information Management - International Conference on Informatics Education \& Research, New Orleans, Louisiana, USA, 14-20.

Sadler-Smith, E. (1997) Learning style: Frameworks and instruments. Educational Psychology, 17 (1 \& 2), 51-63.

Thomas, L., Ratcliffe, M., Woodbury, J. \& Jarman, E. (2002) Learning styles and performance in the introductory programming sequence. SIGCSE Bulletin, 34 (1), 33-37.

van Zwanenberg, N. \& Wilkinson, L. J. (1999). Felder and Silverman's index of learning styles and Honey and Mumford's learning styles questionnaire: How do they compare and do they predict academic performance? The European Learning Styles Information Network Conference, Lancashire, UK.

Zywno, M. S. (2003). A contribution to validation of score meaning for Felder-Soloman's index of learning styles. Proceedings of the 2003 American Society for Engineering Education Annual Conference \& Exposition, Section 2351. Retrieved October 10, 2003 from http://www.ncsu.edu/felderpublic/ILSdir/Zywno_Validation_Study.pdf

Zywno, M. S., \& Waalen, J.K. (2002). The effect of individual learning styles on student outcomes in technology-enabled education. Global Journal of Engineering Education 6(1), 35- 44. Retrieved June 10, 2003 from http://www.eng.monash.edu.au/uicee/gjee/vol6no1/Zywno.pdf

\section{Biography}

Dr Zlatko J Kovačić is a Senior Lecturer in the School of Information Science and Humanities at the Open Polytechnic of New Zealand. Zlatko has a varied academic background and research interests, ranging from core interests relating to IT careers, learning and teaching, to eCommerce, eLearning, time series analysis, multivariate analysis and Web (data) mining. His current research is focused on cognitive processes in distance education using computers and communications technologies.

John Green is a Senior Lecturer in the School of Information Science and Humanities at the Open Polytechnic of New Zealand. He teaches on the Introduction to Information Systems and Technology course. John has presented papers on the topics of eLearning and online pedagogy in the UK, USA, Mexico, Canada, Thailand, Australia and New Zealand. John was visiting fellow at Sukhothai Thammathirat Open University, Bangkok, where he advised the University on elearning development. His current research is on learning styles in distance education and nonverbal online behavior. John is currently writing a course in the Graduate Certificate in Applied elearning for the Tertiary Accord of New Zealand. 